HortSCIENCE 27(7):829-831. 1992.

\title{
Distinguishing Apple Rootstocks by Isozyme Banding Patterns
}

\section{Cyrus Samimy and James N. Cummins \\ Department of Horticultural Sciences, New York State Agricultural \\ Experiment Station, Cornell University, Geneva, NY 14456}

Additional index words. electrophoresis, Malus domestica

\begin{abstract}
Isozymes of six enzyme systems extracted from 13 apple (Malus domestica Borkh.) rootstocks were separated electrophoretically on a horizontal starch gel. Each rootstock was clearly distinguished by its unique isozyme banding patterns. All the rootstocks were distinguishable using only two of the enzyme systems, phosphoglucomutase and 6-phosphogluconate dehydrogenase, both of which exhibited considerable isozyme polymorphism.
\end{abstract}

Most of the apple trees planted in commercial orchards in recent years are on clonal rootstocks. To a large extent, the rootstock determines the relative tree growth rate, ultimate size, anchorage, precocity, productivity, and response to hazards of the soil environment. Therefore, selecting and planting a rootstock cultivar that is true-to-type is essential for the orchardist. Identification or determination of the genetic purity of various rootstocks, based on morphological characters and physiological responses, is costly, time-consuming, and often confounded by environmental conditions.

The technique of isozyme electrophoresis has been very useful in the identification of various apple cultivars (Menendez et al., 1986; Weeden and Lamb, 1985; Weller and Costante, 1986). Menendez et al. (1986) and

Received for publication 31 Oct. 1991. Accepted for publication 10 Feb. 1992. We thank C.S.'s 14-year-old son, Sawson, for drawing the 6PGD isozyme banding patterns by computer. The cost of publishing this paper was defrayed in part by the payment of page charges. Under postal regulations, this paper therefore must be hereby marked advertisement solely to indicate this fact.
Weller and Costante (1986) used polyacrylamide gel electrophoresis to distinguish apple rootstocks by their isozyme phenotypes. In the present study, we used horizontal starch gels and assayed for isozymes that previously have not been used for identification of apple rootstocks. rootstocks. same letters exhibit identical pattern for that enzyme.
Thirteen rootstocks were obtained from our breeding collections. Bark of twigs was used for analysis within a few days after collection in December. About $50 \mathrm{mg}$ of the soft tissue portion of the bark was removed and extracted in $0.2 \mathrm{ml}$ buffer, $\mathrm{pH} 8.0$, containing $0.1 \mathrm{M}$ tris.maleate, $10.0 \%$ glycerol (v/v), $10 \%$ soluble polyvinylpyrrolidone (PVP-40), 0.5\% Triton X-100, and $14 \mathrm{~mm}$ 2-mercaptoethanol. No mercaptoethanol was used in the extraction solutions that were assayed for peroxidase. Samples were kept on ice and thoroughly crushed using a plexiglass rod as a pestle. Paper wicks $(3 \times 8$ $\mathrm{mm})$ were dipped into the crude extracts, blotted on tissue paper to remove excess solution, and inserted into a slit (the origin) across the starch gel (Weeden and Emmo, 1985).

Two buffer systems were used to prepare the starch gel $(10 \%)$ and run the electrophoresis: a tris -citrate/lithium borate buffer at $\mathrm{pH} 8.3$ and a histidine buffer at $\mathrm{pH} 6.5$ (Cardy et al., 1980; Stuber et al., 1988; Weeden, 1984). The tris.citrate/lithium borate gel was used for assaying anodic peroxidase (EC

Table 1 . Isozyme banding patterns ${ }^{z}$ displayed by enzyme systems used to distinguish 13 clonal apple

\begin{tabular}{lcccccc}
\hline \hline & \multicolumn{7}{c}{ Enzyme systems } \\
\cline { 2 - 7 } Cultivars & ADH & GPI & PGM & 6PGD & MDH & Peroxidase \\
\hline 1-Ottawa & A & A & A & A & A & A \\
2-Mark(MAC-9) & A & A & B & B & A & B \\
3-Budagovsky 9 & A & B & C & C & A & C \\
4-Malling 9 & A & A & H & H & A & C \\
5-Malling 27 & A & A & A & D & A & D \\
6-M. Merton 106 & A & A & D & D & B & E \\
7-M. Merton 111 & A & C & E & E & A & C \\
8-Budagovsky 118 & B & A & F & F & A & F \\
9-Budagovsky 490 & A & A & G & G & B & D \\
10-Polish series 2 & C & D & F & I & A & G \\
11-Polish series 16 & D & A & I & A & A & D \\
12-Polish series 18 & C & D & H & J & A & A \\
13-Polish series 22 & C & A & C & J & A & G
\end{tabular}

${ }^{2}$ Patterns displayed by each enzyme were assigned letters. Within each column, rootstocks with the 


\section{ZONE}

\section{$\left.\left.\left.\left.\left.\left.\left.\left.\left.\left.\left.\left.\left.1\right|_{2}\right|_{3}\right|_{4}\right|_{5}\right|_{6}\right|_{7}\right|_{8}\right|_{9}\right|_{4}\right|_{10}\right|_{11}\right|_{12}\right|_{13}$}

A

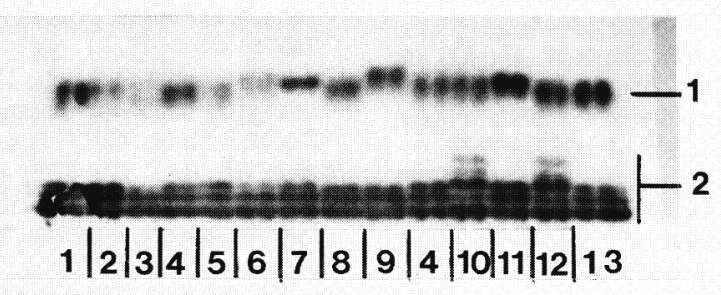

B

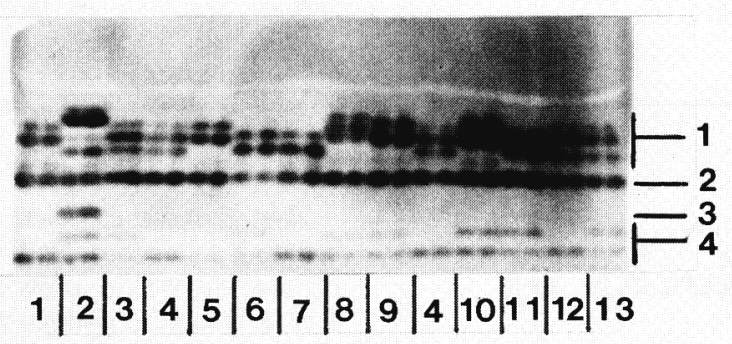

C

Fig. 1. Isozymes of 13 clonal apple rootstocks (1-13). 1, Ottowa; 2, Mark (MAC-9); 3, Budagovsky 9; 4, Malling 9; 5, Malling 27; 6, Malling-Merton 106; 7, Malling-Merton 111; 8, Budagovsky 118; 9, Budagovsky 490; 10, Polish series 2; 11, Polish series 16; 12, Polish series 18; 13, Polish series 22. Isozymes from each rootstock are shown in duplicate. (A) ADH, (B) GPI, (C) PGM. The anode is at the top of the figures.

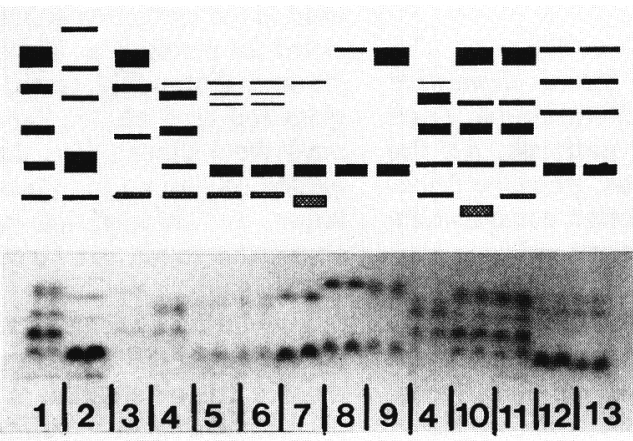

ZONE

A

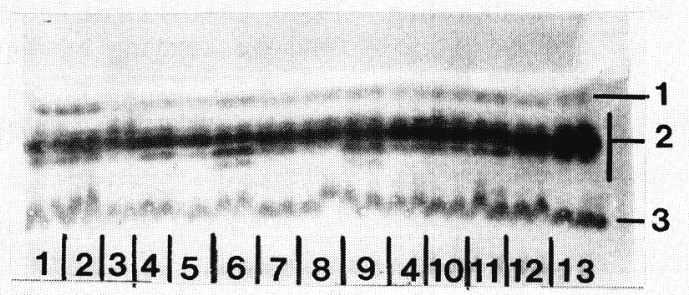

B

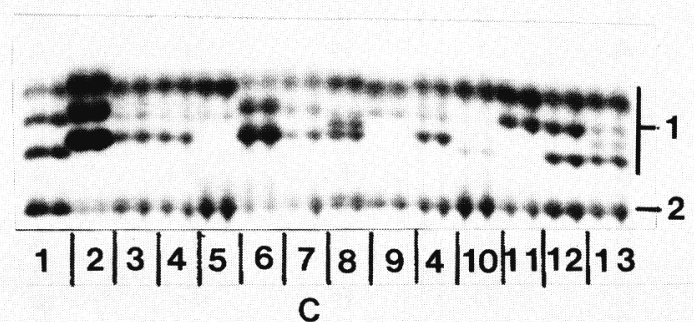

Fig. 2. Isozymes of 13 clonal apple rootstocks (1-13). Refer to Fig. 1 for names of rootstocks. (A) 6PGD, (B) MDH, (C) peroxidase. Isozymes from each rootstock are shown in duplicate. The anode is at the top of the figures.
1.11.1.7) and histidine for phosphoglucomutase (PGM, EC 2.7.5.1), alcohol dehydrogenase (ADH, EC 1.1.1.1), 6-phosphogluconate dehydrogenase (6PGD; EC 1.1.1.44), malate dehydrogenase (MDH; 1.1.1.37), and glucosephosphate isomerase (GPI; EC 5.3.1.9). After the gels were loaded with the wicks; they were placed in a refrigerator at $5 \mathrm{C}$ and run at $50 \mathrm{~mA}$ for tris.citrate/ lithium borate gel and at $30 \mathrm{~mA}$ for histidine for 10 min (Weeden and Emmo, 1985). The wicks were then removed and electrophoresis continued for $\approx 4 \mathrm{~h}$ at $50 \mathrm{~mA}$ or $310 \mathrm{~V}$ for tris.citrate/lithium borate gel and at 30 $\mathrm{mA}$ or $350 \mathrm{~V}$ for histidine. After electrophoresis, the gels were sliced horizontally into 2-mm-thick slabs and stained for the enzymes (Stuber et al., 1988; Weeden and Emmo, 1985; Weeden and Lamb, 1985).

Each of the 13 clonal rootstocks was clearly identified by the isozyme banding patterns of the six enzyme systems studied (Table 1). Different banding patterns of each enzyme exhibited by the cultivars were identified by letters. Considerable polymorphism was observed among the cultivars examined.

$\mathrm{ADH}$ banding patterns separated the rootstocks into four sets in zone 2 (Fig. 1A). They did not show any variability in zone 1 . Budagovsky 118 displayed one intense band and two faint bands in zone 2. Chevreau et al. (1985) have shown, with pollen of apple cultivars, that ADH is a dimeric enzyme and coded by two loci. In their study, most of the apple cultivars exhibited triple bands, two homodimeric and one heterodimeric.

Although the rootstocks exhibited more variability for GPI in zone 1 than in zone $\mathbf{2}$, the activity bands were clearer in zone 2 (Fig. 1B). Rootstocks were separated into two sets on the basis of GPI activities in zone 2. Based on the genetic analysis of GPI isozymes conducted by Weeden and Lamb (1987) on apple cultivars, isozymes in zone 1 , encoded by $G p i-1$, are associated with plastids, and those in zone 2, encoded by Pgi -2 and Gpi3 , are located in the cytosol. GPI has been shown to be a dimeric enzyme (Chevreau and Laurens, 1987; Weeden and Lamb, 1987). Therefore, the triple bands in zone 2 seem to represent two homodimers and one heterodimer generated by $G p i-2$ and $G p i-3$ subunits. The banding patterns exhibited by Polish Series 2 and Polish Series 18 are indicative of heterozygosity at $G p i-2$.

There was considerable variability in PGM activity among the rootstocks (Fig. 1C). PGM was very useful in discriminating among the rootstocks, because it separated the rootstocks into nine sets. All rootstocks exhibited similar isozyme activities in zone 2 . The high-intensity region in zone 1 for Polish series 16 and Polish series 2 are slightly merged triple bands. Weeden and Lamb (1987) found PGM to be a monomeric enzyme and reported five loci for PGM in apple cultivars.

Banding patterns exhibited by 6PGD were more variable than the other five enzyme systems (Fig. 2A). It separated the rootstocks into 10 distinct sets. Although some of the bands were faint and did not appear in the photograph, they were discernible. 
Figure 2A shows the schematic representation of the 6PGD banding patterns. Three loci have been reported to code for 6PGD in apple cultivars (Chyi and Weeden, 1984; Weeden and Lamb, 1987).

MDH was the least variable enzyme system among the rootstocks examined (Fig. 2B). In zone $1, \mathrm{MDH}$ was monomorphic and consisted of two closely migrating bands. Except for Malling-Merton 106 and Budagovsky 490, which showed four bands for MDH in zone 2, the rootstocks exhibited a triple band with the middle band being most intense. MDH has been shown (Weeden and Lamb, 1987) to be a dimeric enzyme with five loci coding its synthesis.

The rootstocks displayed two zones of activities for peroxidase (Fig. 2C). All rootstocks were monomorphic in zone 2 . Rootstocks were separated into seven sets based on peroxidase activities in zone 1 .

Each apple rootstock used in this study was identified by its unique isozyme banding patterns. Reproducibility of the results was confirmed by assaying most of the rootstocks three times. The banding patterns of the isozymes extracted from the soft tissue portion of the bark were similar to those from leaves (data not shown). However, frost-damaged and partially senescent leaves lost some of their isozyme activities. The six enzyme systems used in this study were not all required to identify each of the rootstocks. PGM and 6PGD were sufficient for complete identification of all the rootstocks. Since the rootstocks used in this study exhibit a high degree of isozyme variability, it is very likely that the genetic variability of other rootstock cultivars can be detected by isozyme analysis using horizontal starch gel electrophoresis.

\section{Literature Cited}

Cardy, B.J., C.W. Stuber, and M.M. Goodman. 1980. Techniques for starch gel electrophoresis of enzymes from maize (Zea mays L.). Dept. of Statistics Mimeo Ser. no. 1317, North Carolina State Univ., Raleigh.

Chevreau, E. and F. Laurens. 1987. The pattern of inheritance in apple (Malus $\times$ domestica Borkh.): further results from leaf isozyme analysis. Theoretical Applied Genet. 75:90-95.

Chevreau, E., Y. Lespinasse, and M. Gallet. 1985. Inheritance of pollen enzymes and polyploid origin of apple (Malus $\times$ domestica Borkh.). Theoretical Applied Genet. 71:268-277.

Chyi, Y.S. and N.F. Weeden. 1984. Relative isozyme band intensities permit the identification of the $2 \mathrm{~N}$ gamete parent for triploid apple cultivars. HortScience 19:818-819.

Menendez, R.A., F.E. Larsen, and R. Fritts, Jr. 1986. Identification of apple rootstock cultivars by isozyme analysis. J. Amer. Soc. Hort. Sci. 111(6):933-937.

Stuber; C.W., J.F. Wendel, M.M. Goodman, and J.S.C. Smith. 1988. Techniques and scoring procedures for starch gel electrophoresis of enzymes from maize (Zea mays L.). Tech. Bul. no. 286, North Carolina State Univ., Raleigh.

Weeden, N.F. 1984. Distinguishing among white seeded bean cultivars by means of allozyme genotypes. Euphytica 33:199-208.

Weeden, N.F. and A.C. Emmo. 1985. Isozyme characterization of Kentucky bluegrass cultivars. Can. J. Plant Sci. 65:985-994.

Weeden, N.F. and R.C. Lamb. 1985. Identifica- tion of apple cultivars by isozyme phenotypes. J. Amer. Soc. Hort. Sci. 110(4):509-515.

Weeden, N.F. and R.C. Lamb. 1987. Genetics and linkage analysis of 19 isozyme loci in ap- ple. J. Amer. Soc. Hort. Sci. 112(9):865-872.

Weller, D.L. and F.J. Costante. 1986. Peroxidase zymograms of 16 apple rootstocks. Can. J. Plant Sci. 66:647-652. 